\title{
Simplified Regeneration Protocol for Cycas revoluta Thunb. Mature Zygotic Embryos
}

\author{
Rohangiz NADERI ${ }^{1}$, Khadije MOHAISENI ${ }^{1 *}$, Jaime A. TEIXEIRA DA SILVA ${ }^{2 *}$, \\ Mansour OMIDI ${ }^{3}$, Behjat NADERI ${ }^{3}$ \\ ${ }^{1}$ University of Tehran, Faculty of Agricultural Science and Engineering, Department of Horticulture, 31587-77871, Tehran, Iran; rnaderi@ut.ac.ir; \\ khmohaiseni@ut.ac.ir (*correspondingauthor) \\ ${ }^{2}$ P. O. Box 7, Miki-cho post office, Ikenobe 3011-2, Kagawa-ken, 761-0799, Japan; jaimetex@yahoo.com ('correspondingauthor) \\ ${ }^{3}$ University of Tehran, Faculty of Agricultural Science and Engineering, Department of Agronomy and Plant Breeding, 31587-77871, Tehran, Iran; \\ momidi@ut.ac.ir;bnaderi@ut.ac.ir
}

\begin{abstract}
Mature zygotic embryos of Cycas revoluta Thunb. were used as explants to investigate direct and indirect organogenesis. Explants were incubated on half-strength Murashige and Skoog $(1 / 2 \mathrm{MS})$ basal medium supplemented with various plant growth regulators, singly or in combination (all at $0.5 \mathrm{mg} \mathrm{l}^{-1}$ ): 6-benzyladenine (BA), kinetin (Kin), 2,4-dichlorophenoxyacetic acid (2,4-D), Kin $\times 2,4-\mathrm{D}$, BA×Kin and $\mathrm{BA} \times 2,4-\mathrm{D}$. Cultures were placed at a low light intensity $\left(4 \mu \mathrm{mol} \mathrm{m} \mathrm{s}^{-1} \mathrm{PPFD}\right)$. Adventitious shoot regeneration was observed in the presence of $0.5 \mathrm{mg} \mathrm{l}^{-1} \mathrm{BA}$ after 35 days. The highest number of direct and indirect shoots per zygotic embryo was 3.67 and 29.67 , respectively. Roots were induced on indirect shoots by continuous culture on rooting medium $\left(1 / 2 \mathrm{MS}, \mathrm{p} 0.1 \mathrm{mg}^{1^{-1}} 1\right.$-naphthaleneacetic acid) and hardened successfully in perlite. Each rooted plantlet with pinnate leaves and a primary tap root was individually isolated and acclimatized 185 days after the beginning of culture, with a $10 \%$ success rate.
\end{abstract}

Keywords: 2,4-D, cycads, kinetin, mature zygotic embryo, plant growth regulator

\section{Introduction}

Cycads, an ancient group of plants that has survived from the Permian era and flourished in the Mesozoic and Jurassic periods, are often referred to as 'living fossils' (Gilbert, 1984). Cycas revoluta, of the Cycadaceae family, commonly known as "Japanese sago palm", is native to southern China and Japan (Stevenson, 1990). It is an evergreen and palm-like plant with pinnately divided, glossy green leaves with narrow leaflets that have a sunken midrib and rolled down margins (Gilman, 1999). Cycads are dioecious with males bearing cones and females bearing groups of megasporophylls (Ikeno, 1896).

C. revoluta is a slow-growing plant that requires 3 to 10 years to reach reproductive maturity (Dyer, 1965). Plants are propagated either from seeds, which remain viable for only a short time, or from vegetative offshoots. C. revoluta also demonstrates rapid loss of seed viability and low morphogenic potential, which hinder its conservation as well as favour an effective and rapid mass propagation. Thus, in vitro plant regeneration could be a way to conserve this plant and other endangered species (Ling et al., 2008).

Several attempts have been made to establish a micropropagation protocol based on either somatic embryogenesis or organogenesis (Teixeira da Silva et al.,
2014). In $C$. revoluta, shoot regeneration from zygotic embryos (ZEs) was obtained on Schenk and Hildebrandt (SH) basal medium (Schenk and Hildebrandt, 1972) after 12 weeks in darkness before being transferred to light (Rinaldi and Leva, 1990). Shoot organogenesis from C. revoluta seedling explants was obtained on SH basal medium although shoot morphogenesis did not occur in darkness, but only after transfer to light (Rinaldi and Leva, 1990, 1995). Shoots differentiated and developed from $C$. revoluta $\mathrm{ZEs}$ and seedling explants were successfully grown on $\mathrm{SH}$ or MS medium containing both $0.5 \mathrm{mg} \mathrm{l}^{-1} \mathrm{~N}^{6}$-benzyladenine (BA) and $1 \mathrm{mg} \mathrm{l}^{-1}$ 2,4-dichlorophenoxyacetic acid (2,4-D) (Rinaldi and Leva, 1990) although no attempt was made to optimize the culture procedure. ZEs are a stable and useful explant for regeneration of difficult-to-regenerate species like cycads (Elhiti and Stasolla, 2011).

Motohashi et al. (2008) successfully induced multiple adventitious shoots from mature $C$. revoluta $\mathrm{ZEs}$ in $\mathrm{SH}$ medium supplemented with a combination of BA $(0.20$ to $\left.2.00 \mathrm{mgl}^{-1}\right)$ and 2,4-D (0.00 to $\left.0.20 \mathrm{mg} \mathrm{l}^{-1}\right) 42$ to 84 days after the beginning of culture. Highest proliferation $(88.7 \pm 40.5$ adventitious shoots $\mathrm{ZE}^{-1}$ ) was in the presence of $0.20 \mathrm{mg} \mathrm{l}^{-1}$ $\mathrm{BA}$ and $0.02 \mathrm{mg} \mathrm{l}^{-1}$ 2,4-D. Except for our study, the Motohashi et al. (2008) paper is the only other study that acclimatized $C$. revoluta in vitro-derived plantlets. 
C. revoluta continues to be recalcitrant to in vitro propagation by conventional methods. The objective of this study was to establish a simpler in vitro regeneration protocol (relative to previous attempts in the literature) for shoot regeneration from mature ZEs, and the acclimatization of plantlets.

\section{Materials and methods}

One-month-old seeds from mature plants were collected from the Flower and Plant Research Center, Lahijan, in the north of Iran, and planted in an isolated greenhouse, free from pests and diseases, at the Faculty of Agricultural Science and Engineering, University of Tehran Iran, during 2010 and 2011.

Seeds were surface sterilized for 30 min with a $30 \%$ dilution of $\mathrm{NaOC} 1$ (containing $5 \%$ active chlorine). Following removal of the sclerotesta under sterile conditions, the megagametophytes were surface sterilized - using an in-house developed protocol - by soaking in $70 \%$ ethanol for $2 \mathrm{~min}$ and then in $50 \%$ dilution of $\mathrm{NaOCl}$ (containing 5\% active chlorine) containing 2-3 drops of Tween-20 for $25 \mathrm{~min}$, followed by two rinses with sterile distilled water for 5-10 min each rinse. After surface sterilization, megagametophytes were pooled, longitudinally bisected and the $\mathrm{ZE}$ was excised from each megagametophyte. ZEs 2-cm long were placed on sterile tissue culture media in Petri dishes $(15 \mathrm{~mm}$ deep, $10 \mathrm{~cm}$ in diameter), at three ZEs per Petri dish, and three Petri dishes per treatment. The basal culture medium was Murashige and Skoog (MS; Murashige and Skoog, 1962) macro- and microelements at half the concentration (i.e., $1 / 2 \mathrm{MS}$ ), MS vitamins, $30 \mathrm{~g}^{-1}$ sucrose and solidified with $0.6 \%(\mathrm{w} / \mathrm{v})$ agar. $1 / 2 \mathrm{MS}$ was supplemented with several plant growth regulators, alone and in combination, all at $0.5 \mathrm{mg} \mathrm{l}^{-1}: \mathrm{BA}$, Kin (kinetin or $N^{6}$-furfuryladenine), 2,4-D, Kin $\times 2,4-\mathrm{D}, \mathrm{BA} \times \mathrm{Kin}$ and BA $\times$ 2,4-D. Medium $\mathrm{pH}$ was adjusted to 5.9 with either $1 \mathrm{~N} \mathrm{HCl}$ or $\mathrm{KOH}$ prior to autoclaving at $108 \mathrm{kpa}^{2}$ and $120^{\circ} \mathrm{C}$ for 17 $\mathrm{min}$. Each treatment was repeated three times. All cultures were maintained at room temperature $\left(26 \pm 1{ }^{\circ} \mathrm{C}\right)$ at a low photosynthetic photon flux density of $4 \mu \mathrm{mol} \mathrm{m} \mathrm{m}^{-1}$ and a $16-$ $\mathrm{h}$ photoperiod, and explants were sub-cultured monthly onto the same medium. Elongated shoots $(4-5 \mathrm{~cm}$ long) that formed from any treatment were placed on root initiation medium consisting of $1 \frac{1}{2} \mathrm{MS}$ (half the concentration of macro salts) supplemented with $0.1 \mathrm{mg} \mathrm{l}^{-1} 1$-naphthaleneacetic acid (NAA) (Rinaldi, 1999) and 3\% (w/v) sucrose. Rooted plantlets were transferred to plastic cups filled with perlite and covered with a plastic cup to maintain high relative humidity. The plantlets were placed in a culture room, at the same temperature and light conditions for 1 week, and watered with tap water as necessary. Acclimatized plantlets were then transferred to a greenhouse under natural ambient conditions and watered regularly with tap water. No compost, fertigation or pesticides were used.

Treatments were set up in a factorial arrangement in a completely randomized design (CRD) with three replications per treatment and all experiments were in triplicate. Data were analyzed using $S A S$ software version 9.1. Means were separated by analysis of variance (ANOVA) and significant differences between treatments were determined with Duncan's multiple range test $(\mathrm{DMRT})(P \leq 0.05)$. Percentages were arcsine transformed before statistical analyses.

\section{Results and discussions}

The objective of this experiment was to establish a simplified protocol for shoot production from $C$. revoluta ZEs. Consequently, only direct or indirect organogenesis from callus was quantified and no other morphological parameters were assessed. Under our experimental conditions, $0.5 \mathrm{mg} \mathrm{l}^{-1} \mathrm{BA}$ induced shoots, while all other PGRs, alone or in combination, formed callus. The following responses were observed: 1) formation of friable callus (Fig. 1A) or hard callus (Fig. 1B); 2) direct shoot formation from elongated and enlarged ZEs (Fig. $1 \mathrm{D}, 1 \mathrm{E})$, which developed shoots on the same medium without any further subculture; 3 ) indirect shoot formation in which shoots developed from hard, compact, green callus (Fig. $1 \mathrm{~B}, 1 \mathrm{C}, 1 \mathrm{~F}, 1 \mathrm{G}$ ) after culturing ZEs for 14 days. An average of 3.7 shoots formed from direct regeneration, while 29.7 shoots formed from indirect regeneration and in both cases only in the presence of $0.5 \mathrm{mg} \mathrm{l}^{-1} \mathrm{BA}$ (Tab. 1). Roots developed only from $10 \%$ of shoots (indirect regeneration) within $4-5$ weeks (Fig. $1 \mathrm{H})$. Plantlets formed leaves within 120 days (Fig. 1I) and plantlets 185-days-old (33 plantlets in total) could be acclimatized (Fig. 1J). The development of plantlets from seeds using conventional propagation took 10-12 months (data not shown), indicating that the in vitro route could reduce the regeneration period by half, i.e., hasten regeneration. This is an important aspect when considering the timely rescue, propagation and conservation of endangered cycads, which typically show slow vegetative growth.

Micropropagation protocols for members of the Cycadaceae remain limited. Somatic embryogenesis from ZEs of Zamia spp. (Chavez et al., 1992b) and from ZE- and leafderived callus of adult plants of Ceratozamia (Chavez et al., 1992a, 1992c; Litz et al., 1995), both of the Cycadaceae family, has been successful. Shoots and somatic embryos were induced from megagametophytes and ZEs of the cycad Ceratozamia bildae and C. mexicana cultured on modified B5 (Gamborg et al., 1968) medium containing Kin and 2,4-D (Chavez et al., 1992a). Osborne (1990) reported callus formation on mature ZEs of Encephalartos villosus cultured on SH medium supplemented with $3.0 \mathrm{mg} \mathrm{l}^{-1} \mathrm{BA}$ and $0.3 \mathrm{mg} \mathrm{l}^{-1}$ 2,4-D. Unlike our study in which the same PGR combination resulted in callus formation, Motohashi et al. (2008) induced adventitious shoots from mature C. revoluta $\mathrm{ZEs}$ on $\mathrm{SH}$ medium supplemented with $0.20 \mathrm{mgl}^{-1} \mathrm{BA}$ and $0.02 \mathrm{mgl}^{-1} 2,4-$ D. Creamy, friable callus (Fig. 1A) could not differentiate into any organ. Rinaldi (1999) studied the factors, specifically light and nitrogen formulation, that affected shoot regeneration from C. revoluta ZEs. Rinaldi found that young, immature ZEs could not produce callus, only the oldest ZEs. SH or MS medium, both containing ammonium, promoted shoot formation, but not Klimaszewska and Keller (1985) medium, which contained nitrate. Darkness promoted callus induction, while light promoted shoot formation. Rinaldi and Leva (1995) indicated that shoot regeneration from C. revoluta is strongly connected with the origin and the developmental stage of a cultured explant. When transferred into rooting medium, $80 \%$ of shoots formed roots (Rinaldi, 1999), but no acclimatization was performed. All potted plants (33 in total, all of which survived) appeared morphologically similar to seed-derived plants (Fig. 1I, 1J). This paper provides a simple in vitro to ex vitro protocol for $C$. revoluta. 
64
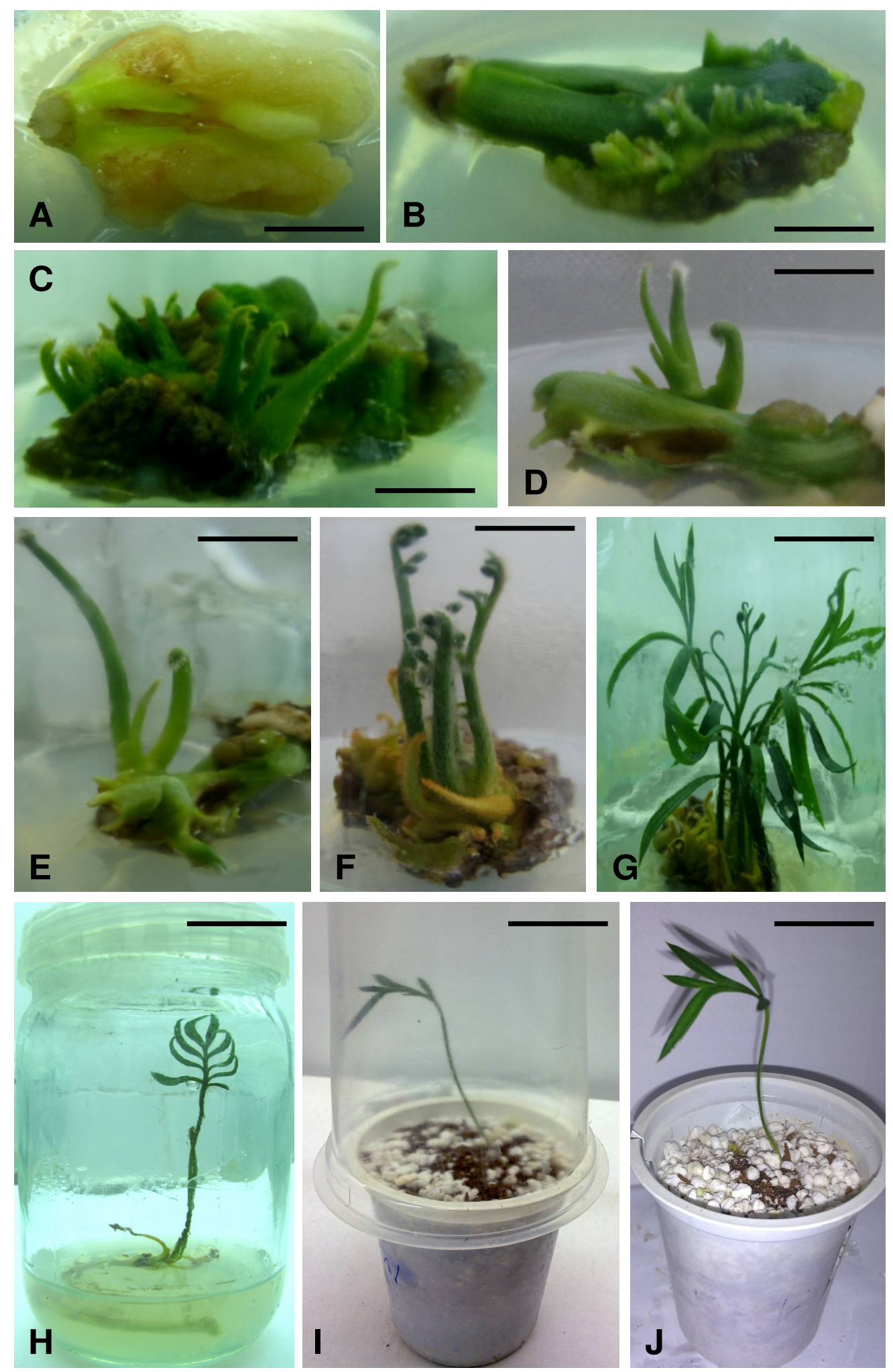

Fig. 1. Micropropagation of Cycas revoluta Thunb. (A) Callus induction from mature zygotic embryo (ZE) 35 days after the beginning of culture in MS basal medium in the presence of $0.5 \mathrm{mgl}^{-1}$ of 2,4-D, Kin, BA $\times 2,4-\mathrm{D}, \mathrm{BA} \times \mathrm{Kin}$ and $\mathrm{Kin} \times 2,4-\mathrm{D}$ combinations (see Table 1). (B) Indirect adventitious shoot bud forming from the callus on a mature ZE 21 days after callus formation on MS medium supplemented with PGRs listed in (A). (C) Indirect adventitious shoots in response to $0.5 \mathrm{mg}^{-1} \mathrm{BA}$ forming at 60 days after callus formation on medium described in (A). (D, E) Direct adventitious shoot formation from mature ZE 45 and 90 days (D and E, respectively) after culture on MS medium supplemented with $0.5 \mathrm{mg} \mathrm{l}^{-1}$ of BA. (F, G) Elongated shoots (pinnate leaves) originating from callus 120 and 185 days (F and G, respectively) after callus formation on MS medium supplemented with PGRs listed in (A). (H) Rooted plantlet in MS $+0.1 \mathrm{mgl}^{-1} \mathrm{NAA}$. (I) Plantlet during hardening in perlite substrate. (J) Acclimatized plantlet. Scale bars: $10 \mathrm{~mm}$ 
Table 1. Effect of plant growth regulators (PGRs), all at $0.5 \mathrm{mgl}^{-1}$, in $1 \frac{1}{2} \mathrm{MS}$ medium on shoot induction of Cycas revoluta zygotic embryos after 35 days in culture

\begin{tabular}{lcc}
\hline PGRs & $\begin{array}{c}\text { Mean number of shoots per mature ZE } \\
\text { (direct shoot formation) }\end{array}$ & $\begin{array}{c}\text { Mean number of shoots per mature ZE } \\
\text { (indirect shoot formation) }\end{array}$ \\
\hline $\mathrm{BA}$ & $3.67 \pm 0.58 \mathrm{a}$ & $29.67 \pm 7.51 \mathrm{a}$ \\
$2,4-\mathrm{D}$ & $0 \mathrm{~b}$ & $0 \mathrm{~b}$ \\
$\mathrm{Kin}$ & $0 \mathrm{~b}$ & $0 \mathrm{~b}$ \\
$\mathrm{BA} \times 2,4-\mathrm{D}$ & $0 \mathrm{~b}$ & $0 \mathrm{~b}$ \\
$\mathrm{BA} \times \mathrm{Kin}$ & $0 \mathrm{~b}$ & $0 \mathrm{~b}$ \\
$\mathrm{Kin} \times 2,4-\mathrm{D}$ & $0 \mathrm{~b}$ & $0 \mathrm{~b}$ \\
\hline Values represent the mean \pm SD $(\mathrm{n}=27$ per treatment); different letters within a column indicate significant differences $(\mathrm{DMRT} ; P \leq 0.05)$. BA, 6-benzyladenine; 2,4- &
\end{tabular}

\section{Conclusions}

This study provides a simple adventitious shoot regeneration protocol from mature zygotic embryos of $C$. revoluta using $0.5 \mathrm{mg} \mathrm{l}^{-1} \mathrm{BA}$ in half-strength $\mathrm{MS}$ basal medium under low light intensity. Indirectly forming a maximum of 29.67 shoots per zygotic embryo, this protocol represents a useful and potential commercial method to mass propagate this cycad with an in vitro to ex vitro route to acclimatization, which still needs further optimization.

\section{References}

Chavez VM, Litz RE, Norstog K (1992a). In vitro morphogenesis of Ceratozamia hildae and C. mexicana from megagametophytes and zygotic embryos. Plant Cell Tiss Org Cult 30:93-98.

Chavez VM, Litz RE, Norstog K (1992b). Somatic embryogenesis and organogenesis in Zamia fischeri, $Z$. furfuracea and Z. pumila. Plant Cell Tiss Org Cult 30:99105.

Chavez VM, Litz RE, Moon PA, Norstog K (1992c). Somatic embryogenesis from leaf callus of a mature gymnosperm Ceratozamia mexicana var Robusta (Miq.) Dyer (Cycadales). In Vitro Cell Dev Biol - Plant 28:59-63.

Dyer RA (1965). The Cycads of Southern Africa. Bothalia 8.4, Pretoria, South Africa.

Elhiti M, Stasolla C (2011). The use of zygotic embryos as explants for in vitro propagation. In: Thorpe TA, Yeung EC (Eds.) Plant embryo culture: methods and protocols. Methods in Molecular Biology, Springer, vol. 710, pp. 229255.

Gamborg OL, Miller RA, Ojima K (1968). Nutrient requirements of suspension cultures of soybean root cells. Cell Res 50:151-158.

Gilbert S (1984). Cycads: status, trade, exploitation and protection. Traffic, Washington, DC. USA

Gilman EF (1999). Cycas revoluta: General information and description. Review paper of Institute of Food and Agriculture Sciences. Environmental Horticulture Department, Florida.
Ikeno S (1896). Spermatozoa of Cycas revoluta. Bot Mag (Tokyo) 10:367-368.

Klimaszewska K, Keller WA (1985). High frequency plant regeneration from thin cell layer explants of Brassica napus. Plant Cell Tissue Organ Cult 4:183-197.

Ling PKA, Thing YS, Gansau JA, Hussein S (2008). Induction and multiplication of callus from endosperm of Cycas revoluta. African J Biotech 7:4279-4284.

Litz RE, Moon PA, Chavez VM (1995). Somatic embryogenesis from leaf callus derived from mature trees of the cycad Ceratozamia hildae (Gymnospermae). Plant Cell Tiss Org Cult 40:25-31.

Motohashi T, Toda M, Kondo K (2008). Adventitious embryo formation derived from zygotic embryos in Cycas revoluta. Plant Biotech 25:589-591.

Murashige T, Skoog F (1962). A revised medium for rapid growth and bioassays with tobacco tissue cultures. Phys Plant 15:473-497.

Osborne R (1990). Micropropagation in cycads. Mem NY Bot Garden 57:82-88.

Rinaldi LMR, Leva AR (1990). Rigenerazione in vitro of Cycas revoluta. Flortecnica 11:2-5.

Rinaldi LMR (1999). Factors affecting shoot regeneration from zygotic embryo and seedling explants of Cycas revoluta Thunb. In Vitro Cell Dev Biol - Plant 35:25-28.

Rinaldi LMR, Leva AR (1995). In vitro organogenesis from diploid tissues of Cycas revoluta Thunb. Plant Cell Tiss Org Cult 43:37-41.

Schenk RU, Hildebrandt AC (1972). Medium and techniques for the induction and growth of monocotyledonous and dicotyledonous plant cell cultures. Can J Bot 50:199-204.

Stevenson DW (1990). Morphology and systematics of the Cycadales. Mem NY Bot Garden 57:8-55.

Teixeira da Silva JA, Woodenberg W, Zeng SJ (2014). Cycads in vitro. Plant Tissue Cult Biotech 24(2):287-301. 